\title{
Impact of main tillage methods on weed infestation of crops in the winter maize, wheat, dried peas rotation
}

\author{
Khasan Tarchokov, Magomed Chochaev, and Julietta Tutukova \\ Institute of Agriculture - Branch of the Kabardino-Balkarian Scientific Center of the Russian \\ Academy of Sciences, 224, Kirova Street, 360004 Nalchik, Kabardino-Balkarian Republic
}

\begin{abstract}
The paper presents ways of suppressing weed plants, including a complex of agricultural practices aimed at reducing their harmful effects and further distribution. Many methods to control weed vegetation are known in the field cultivation technology. They differ in terms of the amount of expired costs and labor, economic and technical efficiency. As a result of our research, the impact of some tillage methods on the effectiveness of weed suppression on the main field crops in selected Kabardino-Balkaria natural climatic conditions is identified. The goal of the research is to determine the effectiveness of main tillage methods on the Ciscaucasian carbonate chernozems in different zones of the republic. In research conducted in 2015-2018 in the Kabardino-Balkaria steppe zone in crop rotation, with an alternation of maize-winter wheat-pea crops in the suppression of weed plants, a soil treatment system is allocated when the soil treatment on $12-14 \mathrm{~cm}$ is combined with plowing to a depth of $25-28 \mathrm{~cm}$ with the use of related chemical herbicides of various spectrum of actions.
\end{abstract}

\section{Introduction}

One of the main problems of the agricultural industry worldwide is the harmful effects of the weed-field community on agricultural crops. Obviously, without proper science-based control, it is meaningless to undertake activities aimed at increasing and maintaining soil fertility, protecting crops from known pathogens, pests [8,9]. The effectiveness of different methods of weed suppression on agricultural crops in our earlier studies has been thoroughly studied and found application in agricultural products of different forms of ownership of Kabardino-Balkaria [1, 2].

Multiple studies have found that nonmoldboard tillage with high impact protects the soil from deflation and water erosion processes that contribute to moisture conservation in the soil $[3,4]$. At the same time their high economic efficiency is proved, but its technical efficiency in terms of decreasing the number of weed plants is observed.

It should be noted that at present, there are still problems of soil cultivation aimed at the principles of resource and energy conservation. Therefore, on the Ciscaucasian carbonate chernozems of heavy granulometric composition, we conducted researches, which were necessary due to the fact that recently (not only in Kabardino-Balkaria) agricultural vehicles 
and tractors of new modernization, new chemical preparations of various selectivity and environmental friendliness have entered the market.

\section{Materials and Methods}

The research was carried out in the steppe zone of Kabardino-Balkaria (Opytny village, Tersky district of the Kabardino-Balkarian Republic) (Table 1). The average annual temperature was $10.1^{\circ} \mathrm{C}$.

Table 1. Meteorological indicators for research years (According to the Kuyan agrometeorological post, Opytny village, Tersky district of the Kabardino-Balkarian Republic)

\begin{tabular}{|l|c|c|c|}
\hline \multicolumn{1}{|c|}{ Year } & Air temperature, ${ }^{\circ} \mathbf{C}$ & Rainfall, $\mathbf{~ m m}$ & $\begin{array}{c}\text { Relative air humidity, } \\
\text { \% }\end{array}$ \\
\hline 2015 & 12.6 & 12.6382 .9 & 70.3 \\
\hline 2016 & 14.0 & 571.1 & 72.6 \\
\hline 2017 & 11.3 & 387.0 & 73.8 \\
\hline 2018 Long-term average \\
$\begin{array}{l}\text { annual data } \\
\text { (standard) }\end{array}$ & 11.4 & 470.0 & 73.3 \\
\hline
\end{tabular}

The amount of precipitation $(452.7 \mathrm{~mm})$ and relative air humidity $(72.5 \%)$ during the years of the research were practically within the normal range (long-term average annual data).

The humus content in the arable soil layer was in the range of 3.0-3.5\%; $\mathrm{P}_{2} \mathrm{O}_{5}$ (according to Machigin) - $0.14-0.27 \% ; \mathrm{K}_{2} \mathrm{O}$ (according to Machigin) - 0.2-2.6\%; $\mathrm{PH}-6.8-7.0 \%$. Average annual precipitation - 340-400ml [10].

In the experiments, maize seeds zoned for the steppe zone of Kabardino-Balkaria were used: Kabardinskaya 3812 variety - a hybrid population (originator of Institute of Agriculture of the Kabardino-Balkarian Scientific Center of the Russian Academy of Sciences), belongs to the late-ripening group (FAO-600), grain yield on the irrigation reaches $9.5 \mathrm{t}$ and more, silage mass - 55.0-60.0t. It responds positively to a high agricultural background.

Peas. Aksaysky usatiy-55 variety (originator - Donskoy zonal Research Institute of Agriculture), belongs to the mid ripening group of varieties with a growing season of 85-90 days, leafless. Seeds are spherical, smooth with a sign of non-shedding, yellow. The weight of 100 seeds is $17-235 \mathrm{~g}$ with a protein content in the grain of $25-27 \%$ and a maximum grain yield of 4.5-4.9 t/ha. Resistance to lodging, shedding and drought are high.

Winter wheat. Yuzhanka variety, bred by the Institute of Agriculture of the KabardinoBalkarian Scientific Center of the Russian Academy of Sciences, has a high yield (6.5-7.9 $\mathrm{t} / \mathrm{ha}$ ) on condition of irrigation and good predecessors (peas, soybeans, perennial grasses). Resistant to lodging, pests and diseases.

The experiment scheme consisted of three types of main tillage for seeding maize, winter wheat and peas:

1. Cultural tillage $(25-28 \mathrm{~cm})$

2. Minimum tillage $(12-14 \mathrm{~cm})$

3. Shallow tillage $(6-8 \mathrm{~cm})$.

Main tillage methods. In order to suppress some species of perennial weeds (Johnson grass, species of sow thistles, bindweed, etc.) after the winter wheat and peas were harvested against the background of light primary tillage with tools such as LDG, Roundup + Banvel herbicides were used at dosages of 5.0 and $0.1 \mathrm{l} / \mathrm{ha}$. The preparations were applied to vegetative weeds with an average height of $10-15 \mathrm{~cm}$ with a working solution consumption of 250-300 1/ha in the summer-autumn period (August-September). 
On peas areas for "blind" harrowing in the spring Prometrin (Gezvgard) at a dose of 3.5 1/ha and Bazagran at a dose of 3.5 1/ha were used in the phase of 3-5 leaves of the crop. Maize areas were treated in the phase of $3 \pm 5$ leaves of the crop. The winter wheat was treated in the tillering phase in spring with Banvel (0.2 l/ha) + a mixture of falcon and Bi-58 (1.2 l/ha), and karate $(0.2 \mathrm{l} / \mathrm{ha})$ was introduced during the appearance of flag leaf.

For winter wheat and corn areas, $\mathrm{N}_{90} \mathrm{P}_{60} \mathrm{~K}_{60}$ was applied, including $\mathrm{N}_{70}$ as a top dressing, nitrogen fertilizers were not applied on pea crops and $\mathrm{P}_{90} \mathrm{~K}_{60}$ was used for cultivation in the spring before seeding.

In the experiments, the weed infestation of crops was determined by quantitative-specific and qualitative-weight methods. [5, 6] The yield of the tested crops was determined on a plot basis, after which it was brought to $100 \%$ purity and standard moisture, calculated in tons per hectare planted area.

The agricultural technique of crop cultivation in crop rotation was in line with the recommended parameters for production crops. The by-products of maize, winter wheat and peas were crushed in the field and planted in the soil. The tillage was carried out with a DT75 tractor with an agricultural tools (BDT-3.0 - for grinding of shredded residues after grain maize); disc cultivators (LDG-10) for treatment of the stern after winter wheat and peas, PN4-35 plows, KPS-4.0, KPN-5.6 cultivators; SZ-3.6 seeders were also used The experimental material was statistically processed by the dispersion analysis according to Dospekhov [6].

\section{Results and Discussion}

Various main tillage methods in the short crop rotation (corn-winter wheat-peas) on average slightly changed practically the soil moisture with its agrophysical properties over the period 2015-2018. Thus, the amount of productive moisture in the $0-100 \mathrm{~cm}$ soil layer for surface and minimum tillage was 152.0 and $150.0 \mathrm{~mm}$, respectively. In the cultural plowing variant, these figures were slightly higher $-160.5 \mathrm{~mm}$. The soil density of $0-30 \mathrm{~cm}$ soil layer on average in spring ranged from 1.09 to $1.12 \mathrm{~g} / \mathrm{cm}^{3}$ in the variant with cultural tillage, minimal and shallow methods of main tillage.

The determination of the weed infestation of experimental plots prior to the use of herbicides in the post-harvest period showed that the main weeds of field crops under the conditions of the research were Johnson grass (Jardium Jalepense Pers.J), species of sow thistles (Jonchis arvensis.J.), and bindweed (Jonchis arvensis.J.) (Convolvulus arvense.j.). The young gramineous-dicotyledonous weed plants were a part of the redroot pigweed (Amazantus vulgaris.J.), field mustard (Jinapis arvensis.J.),regweed (Amdrozia artemisiafolia.J.), etc.

As can be seen from Table 2, the different types of main tillage in the crop rotation had a corresponding impact on the level of crop infestation.

Table 2. The effectiveness of the main tillage methods and herbicides on crops in the short rotation (the number of weeds, $\mathrm{pcs} / \mathrm{m}^{2}$ on average over the years of research)

\begin{tabular}{|c|c|c|c|}
\hline \multirow{2}{*}{$\begin{array}{l}\text { Terms of accounting for } \\
\text { weed infestation } \\
\text { by crops }\end{array}$} & \multicolumn{3}{|c|}{ Main tillage methods } \\
\hline & $\mathbf{1}^{+)}$ & $2^{+)}$ & $3^{+)}$ \\
\hline \multicolumn{4}{|c|}{ Maize (on average for $2015-2018$ ) } \\
\hline $\begin{array}{l}\text { Summer-autumn before the } \\
\text { use of the herbicide mixture } \\
\text { (average for 2014-2016) }\end{array}$ & $52-7 *)$ & $57-12 *)$ & $69-19 *)$ \\
\hline $\begin{array}{l}\text { Before the spring cultivation } \\
\text { of the plow }\end{array}$ & $95-2$ & $110-4$ & $140-4$ \\
\hline Before the grain harvesting & 12 & 22 & 24 \\
\hline
\end{tabular}


Table 2. Continued

\begin{tabular}{|c|c|c|c|}
\hline \multicolumn{4}{|c|}{ Dried peas (on average for $2015-2017$ ) } \\
\hline $\begin{array}{l}\text { Before chemical weeding of } \\
\text { crops in spring }\end{array}$ & $68-12$ & $85-20$ & $90-27$ \\
\hline $\begin{array}{l}2 \text { weeks after chemical } \\
\text { weeding }\end{array}$ & $25-2$ & $30-3$ & $35-3$ \\
\hline Before the grain harvesting & $12-1$ & $11-2$ & $10-1$ \\
\hline \multicolumn{4}{|c|}{ Dried winter wheat } \\
\hline $\begin{array}{l}\text { Before chemical weeding of } \\
\text { the stubble (summer-autumn } \\
\text { 2016-2018) }\end{array}$ & $78-15$ & 83-19 & $85-20$ \\
\hline $\begin{array}{l}\text { In spring during the renewal } \\
\text { of vegetation (2016-2018) }\end{array}$ & 8 & 12 & 16 \\
\hline Before harvesting & 17 & 20 & 27 \\
\hline \multicolumn{4}{|c|}{$\begin{array}{l}\text { Note: } \\
\text { 1. Cultural tillage }(25-28 \mathrm{~cm}) \\
\text { 2. Minimum tillage }(12-14 \mathrm{~cm}) \\
\text { 3. Shallow tillage }(6-8 \mathrm{~cm}) \\
\text { *) The first number is the young gramineous-dicotyledonous group of weeds; the second - from the } \\
\text { group of perennial weeds (mainly species of sow thistles and bindweed). }\end{array}$} \\
\hline
\end{tabular}

Thus, in maize crops planted after winter wheat, the smallest amount of weed plants before the use of chemical weeding in the summer-autumn period was recorded on a variant with cultural plowing - 52 plants of young weeds and 7 - perennial ones. For the variants of minimum $(12-14 \mathrm{~cm})$ and surface tilling, the values were 57-69 and 12-19 young and perennial weed species, respectively. Before the first spring cultivation of the plow and before the corn harvesting, the efficiency of weed suppression increases rapidly. On the background of cultural plowing, they do not exceed $25.0 \mathrm{pcs} . \mathrm{m}^{2}$ for a small amount $(2.0$ plants per 1 sq.m.) of perennials. Before harvesting maize grain, cultivated plowing for its crops in combination with chemical weeding of stubble from under winter wheat in summerautumn period and during the growing season, practically cleared the crops of perennials. A small amount of young weeds $\left(12.0-24.0 \mathrm{pcs} . / \mathrm{m}^{2}\right)$ were underdeveloped and had no negative impact on the crop. The pea crops following the late harvesting of drain maize were not treated with a sustainable herbicide of a general destructive nature. Therefore, our research on this culture was aimed at determining the effectiveness of the use of Prometrin (a soil preparation) and Bazagran for seedlings in the 3-5-leaf phase of the crop in weed control in the context of various forms of main tillage. As can be seen from the given data in Table 2, the main tillage methods had an effect on the degree of weed infestation of crops. In the variant with cultural tilling before the use of herbicides, the amount of young weeds decreased from 85-90 to 68, perennials - from 20.0-27.0 to 12.0 plants per $1 \mathrm{~m}^{2}$.

The suppression efficiency of weeds is sharply increased when chemical weeding is applied against the background of various main tillage methods, where the total amount of weeds was only 27 versus 80 or $66.7 \%$ of their suppression. In variants with minimal and shallow methods of main tillage, these indicators were 58.3 and $68.0 \%$. By the harvest period, the level of weed infestation of pea crops continued to decline, and was limited to between 11.0 and 13.0 plants per $\mathrm{m}^{2}$ of area.

On the crops of winter wheat, placed on pea stubble for grain, the initial amount of weeds before various methods of main tillage and the use of chemical weeding in the summerautumn period was $78.0-85.0$ plants of young weeds and $15-20 \mathrm{pcs} / \mathrm{m}^{2}$ of perennials. In the spring, during the resumption of vegetation, there is a high degree of suppression of both 
young and perennial weeds from the combined action of main tillage + general destructive herbicides used in summer-autumn period and during the Banvel vegetation period $-0.21 /$ ha

However, to the greatest extent, the technical efficiency of herbicides can be seen against the background of cultural tillage, where the total amount of weeds in spring during the renewal of the growing season did not exceed 8.0 versus 12.0 and 16.0 plants per $1 \mathrm{~m}^{2}$ against the background with minimal and shallow main tillage methods.

In the technology of suppressing weeds on crops of agricultural plants, along with the quantitative and species composition, the determination of their quantitative-weight $\left(\mathrm{g} / \mathrm{m}^{2}\right)$ composition of the weed-field community is of paramount importance $[5,3]$. As can be seen from Table 3, in our research for the harvesting period, the total amount of weed plants per $1 \mathrm{~m}^{2}$ was between 12.0 and 23.0 for all crops.

Table 3. Impact of different main tillage methods on weed infestation of crops ${ }^{+}$and carrying out of nutrients in the link of short crop rotation before harvesting

\begin{tabular}{|c|c|c|c|}
\hline \multirow{2}{*}{$\begin{array}{c}\text { Crop and time of accounting for weed infestation } \\
\text { of crops }\end{array}$} & \multicolumn{3}{|c|}{ Main tillage methods } \\
\hline & $1 *)$ & $2 *)$ & $3 *)$ \\
\hline Maize (average for 2014-2016) & $23-170^{+1}$ & $27-210^{+}$ & $\begin{array}{c}29- \\
230^{+)}\end{array}$ \\
\hline Peas (average for 2015-2017) & $25-150$ & $29-170$ & $33-190$ \\
\hline Winter wheat (average for 2016-2018) & $12-110$ & $15-140$ & $20-155$ \\
\hline Total weight of weeds (average for crops); $\mathrm{g} / \mathrm{m}^{2}$ & 430 & 520 & 575 \\
\hline \multicolumn{4}{|c|}{ Nutrients carried out of the soil by weeds; $\mathrm{kg} / \mathrm{ha}$ : } \\
\hline Nitrogen & 67 & 79 & 83 \\
\hline Phosphorus & 25 & 30 & 36 \\
\hline Potassium & 86 & 106 & 109 \\
\hline
\end{tabular}

Note:

1. Cultural tillage $(25-28 \mathrm{~cm})$

2. Minimum tillage $(12-15 \mathrm{~cm})$

3. Shallow tillage $(6-8 \mathrm{~cm})$

${ }^{+)}$The numerator is the amount; denominator - their wet aboveground weight in $\mathrm{g} / \mathrm{m}^{2}$

In variants with minimal and shallow main tillage methods, they occupied the limits of $15.0-29.0$ and 20.0-29.0 pics. $/ \mathrm{m}^{2}$, respectively.

However, when considering these data by determining their weight per unit of planted area, there is a clear and visible difference in efficiency of weed suppression compared to the different main tillage methods. Thus, in our experiments, the largest amount by weight of aboveground wet weight $\left(\mathrm{g} / \mathrm{m}^{2}\right)$ was recorded in the third variant (shallow tillage to a depth of $6-8 \mathrm{~cm})-575.0 \mathrm{~g} / \mathrm{m}^{2}$. In second place is the variant where the minimum $(12-15 \mathrm{~cm})$ tillage is carried out $-520.0 \mathrm{~g} / \mathrm{m}^{2}$.

In the variant with cultural tillage $(25-28 \mathrm{~cm})$, these indicators did not exceed $430.0 \mathrm{~g} / \mathrm{m}^{2}$. The reviewed data also show that this mass of $430.0 \mathrm{~g} / \mathrm{m}^{2}$ carries out the smallest amount of nitrogen $(67.0 \mathrm{~kg} / \mathrm{ha})$, phosphorus $(25.0 \mathrm{~kg} / \mathrm{ha})$ and potassium $(86.0 \mathrm{~kg} / \mathrm{ha})$ from the soil. The variants with minimum and shallow main tillage were: nitrogen 79.0 and $83.0 \mathrm{~kg} / \mathrm{ha}$, phosphorus 30.0 and $36.0 \mathrm{~kg} / \mathrm{ha}$ and potassium 106.0 and $109.0 \mathrm{~kg} / \mathrm{ha}$, respectively.

These data indicate that even with a smaller number of weeds before harvesting, but with a greater mass, they remove a greater amount of nutrients from the soil.

Along with a change in the weed infestation of crops, various main tillage methods in combination with chemical weeding and without it, influenced the processes of the formation of the productivity of experimental crops (Table 4).

According to the research results, the highest yields of maize grain (on average for 20152018) were obtained on the variant with cultural tilling $(25-28 \mathrm{~cm})-7.8 \mathrm{t} / \mathrm{ha}$. These results 
exceed the data obtained on the variants with the minimum $(12-15 \mathrm{~cm})$ and shallow $(6-8 \mathrm{~cm})$ main tillage methods by 1.3 and $3.8 \mathrm{t} /$ ha compared to the grain yield formulated under the condition of maize placement against the background of cultural plowing.

On the peas and winter wheat areas, grain productivity against the background of cultural tilling was also the highest, occupying the limits of 3.2 and $4.5 \mathrm{t} / \mathrm{ha}$ versus 2.8 and $3.0 \mathrm{t} / \mathrm{ha}$ against the background of minimal and shallow tillage methods.

Table 4. The impact of the main tillage methods and chemical weeding on the grain productivity of crops in the link of the short crop rotation

\begin{tabular}{|l|c|c|c|}
\hline \multirow{2}{*}{ Main tillage methods } & \multicolumn{3}{|c|}{ Yield (t/ha) } \\
\cline { 2 - 4 } & maize (2015- 2018) & peas (2015-2017) & $\begin{array}{l}\text { winter wheat (2016- } \\
\text { 2018) }\end{array}$ \\
\hline Cultural tillage (25-28cm) & $7.8-8.3^{+)}$ & $3.2-4.5^{+)}$ & $\left.4.5-5.9^{+}\right)$ \\
\hline Minimal (12-15 cm) & $6.5-7.0$ & $2.8-3.7$ & $4.3-5.6$ \\
\hline Shallow (6-8 cm) & $4.0-6.3$ & $2.0-3.0$ & $3.0-4.6$ \\
\hline HCP-05 & 0.30 & 0.05 & 0.4 \\
\hline
\end{tabular}

${ }^{+}$Note: backgrounds of chemical weeding: the first number - no herbicide; the second - with the use of herbicides

The efficiency of main tillage methods is improved and characterized by the higher productivity of the studied crops, while the weeds are suppressed with the aid of chemical weeds. However, the grain productivity of winter wheat in variants with cultural tillage and minimal main tillage was almost identical (4.3-4.5 t/ha on a herbicide-free) against 5.6-5.9 $\mathrm{t} / \mathrm{ha}$ on a herbicide. With shallow tillage, these rates reliably decrease to 3.0 and $4.6 \mathrm{t} / \mathrm{ha}$.

The average crop yield of maize on a herbicidal background for all studied main tillage methods was 7.2 compared to $6.1 \mathrm{t} /$ ha without the use of herbicides. The same pattern applies to pea crops (3.7 and $2.7 \mathrm{t} / \mathrm{ha})$ and winter wheat crops (4.3 and $3.4 \mathrm{t} / \mathrm{ha})$.

\section{Conclusion}

1. Weed control techniques for maize, winter wheat and peas (short rotation phase) should consist of basic and preharvest tillage, use of herbicides and their combinations in different periods - summer-autumn, growing season, which makes it possible to reduce the pollution of crops with a high technical effect.

2. The use of cultural $(25-28 \mathrm{~cm})$ and minimum $(12-15 \mathrm{~cm})$ tillage as the main tillage produces the highest yield of the seasonal crop rotation. With further minimization (shallow $6-8 \mathrm{~cm}$ ) of main tillage for maize, peas and winter wheat, grain yields are reduced by $2.0 ; 1.5$ and $2.9 \mathrm{t} / \mathrm{ha}$, respectively.

3. In order to increase the technical and economic efficiency of chemical weeding in fields with the placement of maize, peas and winter wheat with mixed type of weed infestation of crops, it is necessary to use general-purpose herbicides in the summer-autumn period after the harvesting of peas and winter wheat.

4. Cultural tilling provided that winter wheat is placed over dried peas does not have a reliable advantage in the formation of grain productivity compared to the data obtained in the minimum $(12-15 \mathrm{~cm})$ main tilling method of the Ciscaucasian carbonate chernozems of heavy granulometric composition. 


\section{References}

1. P.N. Yaroslavskaya, Peculiarities of weed control on oilseeds with anti-erosion soil cultivation. Scientific bases of soil protection agriculture in the Krasnodar Territory, (1998)

2. Kh.Sh. Tarchokov, Technology for growing high yields of peas in Kabardino-Balkaria, (2020)

3. Kh.A. Malkanduev, Kh.Sh. Tarchokov, M.M. Chochaev et al, Agrotechnology of a new generation in an adaptive landscape farming system for various natural and climatic zones of the Kabardino-Balkar Republic (2020)

4. Kh.Sh. Tarchokov, D.A. Tutukova, Rolling the soil and harvest of field crops (2020)

5. A.V. Fisyunov, Weed Control Handbook (1984)

6. A.V. Armor, Field experiment technique (1985)

7. Kh.Sh. Tarchokov, Agriculture, 37 (2014)

8. Kh.Sh. Tarchokov et al., Agrotechnology of a new generation in an adaptive landscape farming system for various natural and climatic zones of the KBR (2020)

9. Agrotechnological assessment, design of adaptive landscape systems of agriculture and agricultural technologies, edited by Acad. IN AND. Kiryushina, acad. A.L. Ivanova (2005)

10. K.N. Kerefov, B.Kh. Fiapshev, Soil regions of Kabardino-Balkaria and their agricultural characteristics (1968) 